\title{
PREREQUISITES FOR EMOTIONAL INTELLECTUAL DEVELOPMENT
}

\author{
Zarytska V. V., Falko N. M.
}

\section{INTRODUCTION}

This section reveals the biological and social prerequisites for the development of emotional intelligence. In particular, the peculiarities of the functioning of the brain, the principles of nervous system development and the principles of learning, which determine the biological preconditions of human intellectual development, the content of the most essential biological preconditions such as: hereditary inclinations of emotional abilities and emotional perception; right-wing type of thinking; properties of temperament; features of information processing.

The social essence of man is grounded according to the theory of J. Piaget, the basic social prerequisites for the development of emotional intelligence are identified and characterized, namely: syntonicity in childhood, development of rationality as he grows up, level of development of self-awareness, emotional and emotional awareness, abundance, gender peculiarities of education, androgyny, external locus of control, religiosity, which, in our opinion, will contribute to a more informed choice of ways to develop emotions young people in the process of their professional training.

\section{Biological Prerequisites}

\section{for the Development of Emotional Intelligence}

A diverse study of human life includes the study of the nature and diversity of human intelligence. Analysing recent discoveries in the field of brain research, G. Gardner, in particular, concluded that there is a relationship between the flexibility of human development and the nature or nature of intellectual abilities. On the one hand, changes can be viewed as a relatively stable process in which they occur partly, and on 
the other hand, development is characterized by flexibility and plasticity. If a person exerts purposeful influence from the outside during a certain critical period, then the body acquires significantly more persistent abilities (or restrictions) as a result than in the case of spontaneous influences. It is important to identify those types of external influences that are most effective, as well as to understand the timeliness of using them to make significant positive changes. Only in this case it could be possible to determine which development models will produce better results and help the person to fully develop his intellectual potential ${ }^{1}$. As to the nature of intellectual abilities that a person is capable of developing, there are two positions here: one position supports the idea that there is a general intelligence, through which a person is empowered, a mechanism of versatile information processing that can be used in an unlimited number of cases; the second point is that its adherents assert a person's inclination to perform certain intellectual operations and inability to perform others. It turns out that we need to understand how well the individual parts of the brain and nervous system are prepared to perform these separate operations, as well as to identify and explain those abilities (such as speech) that are largely possessed by all normal people and those possessed by fewer people (music, artistic ability, etc.), and how biologically these phenomena are. Based on research in the sphere of the brain and nervous system, other biological processes that determine the biological preconditions for the development of emotional intelligence, for example, I. Andreeva ${ }^{2}$ calls the most significant among them: hereditary inclinations of emotional abilities and emotional perception; right-brain type of thinking; properties of temperament; features of information processing. Emotional ability is characterized by the degree of successful adaptation of emotional response to a stimulus to circumstances: for persons with highly developed emotional ability is characterized by the combination of satisfaction of personal needs with the interests of society, and poorly developed emotional ability is partly hereditary and implies immature

\footnotetext{
${ }^{1}$ Гарднер Г. Структура разума: теория множественного интеллекта / Г.Гарднер. - М. : Вильямс, 2007. -512 с.

${ }^{2}$ Андреева И.Н. Предпосылки развития эмоционального интеллекта / И.Н. Андреева // Вопросы психологии. - 2007. - № 5. - С. 57-65.
} 
and not developed feelings ${ }^{3}$. It is proved that the difference between the genotype (the construction of the organism due to the genes of both parents) and the phenotype (externally expressed characteristics of the organism, which in some way manifest in specific conditions) plays an extremely important role in understanding the behaviour and intellectual profile of any person, though not less of great importance is the presence of variability in the structure of the body, since each parent receives a large number of genes that can be combined in an unlimited number of combinations, so you shouldn't be surprised that any two people (except identical twins) do not resemble each other, or that any two people are similar intellectual profile. No one disputes that physical qualities are explicitly genetically determined and that peculiarities of temperament also depend on the genetic set, but when it comes to features of a person's cognitive behaviour or personality, the above statement is not so convincing. The only thing to say here is that in the presence of equal conditions in genetically predisposed to a certain kind of thinking or activity of people, the development of the latter will be more intense. Along with the genetic justification of biological prerequisites for the development of intelligence, there is a viewpoint of neuroscience. A key term necessary to understand the development and improvement of the nervous system is sewage, which means the tendency of any organ system (such as the nervous system) to act in the development process in certain ways. Nerve combinations are not accidental, they are due to high-precision biochemical control, epigenetic control, epigenetic sequence and are the basis for further development. This development is extremely flexible, plastic. The body demonstrates its plasticity in various ways, depending on the age of the person, external influences, lifestyle and nutrition, training and education, etc. If it is difficult for a person to give certain types of knowledge or activity, then they say that there is no inclination for these types of knowledge or activity. There are several principles of plasticity in the development of the nervous system as a basis for the development of intelligence (including emotional). The

\footnotetext{
${ }^{3}$ Андреева И.Н. Биологические и социальные предпосылки развития эмоционального интеллекта / И.Н. Андреева // Когнитивная психология: сб. ст. / [под ред. А.П. Лобанова, Н.П. Радчиковой]. - Минск: БГПУ, 2006. - С. 7-11.
} 
first principle is maximum flexibility in the development of the body occurs in early childhood. Therefore, it is no coincidence that intensive development of the child is necessary in the early stages of life. The second principle is the development of the nervous system in critical periods of development of an organism is of particular importance. The third principle is the degree of flexibility depends on the area of the nervous system. For example, the anterior lobes of the corpus callosum, which connects the two hemispheres of the brain, develop later and are more flexible than those formed in the first days or weeks of a baby's life, such as the sensory cortex. The high level of non-fixation of some parts of the nervous system, such as the corpus callosum, indicates that it is given the opportunity to adapt to external influences. Depending on living conditions the individual brain units develop differently. Fourth principle is the dependence of the nervous system on external influences (positive and negative). Fifth principle is the long-lasting effect of an injury, which may not initially manifest a marked disruption in the development of the nervous system, but for a long time will slow down the intensity of this development.

The most important apparatus of human mental activity are the large hemispheres of the cerebral cortex. A. Luria ${ }^{4}$ notes that the human brain is a complex and highly differentiated apparatus, which consists of many parts, each of which performs its functions, but their work is closely interrelated and the malfunctioning of any part affects the work of the whole brain. He identifies three major brain «blocks» that provide reception, processing of information, creation of programs of their own actions and control their successful implementation, but always work as a whole. The first «block» supports the required tone of the cerebral cortex, necessary for both the processes of obtaining and processing information, as well as the processes of program formation and control over their execution proceeded successfully. The physiological characterization of the optimum tonus of cerebral cortex tone was given in due time by I. Pavlov, who pointed out that processes occurring in the normal cerebral cortex are subject to the «law of force», according to

\footnotetext{
${ }^{4}$ Реан А.А. Социализация агрессии / А.А. Реан, Я.Л. Коломинский // Социальная педагогическая психология. - СПб., 1999. - 398 с.
} 
which a strong (because the most significant) indicator causes a strong reaction that leaves the most stable mark, while a weaker (or less significant) stimulus causes a weaker reaction, which is more rapidly attenuated or more easily inhibited. The existence of such a «law of force» is necessary for any organizational selective activity: to create dominant (most important) systems of excitation, to preserve organized systems and information and sustainable behaviour programs. By reducing the tone of the cortex, it (behaviour) can go into a braking state. This feature of the brain, for example, in a drowsy or half-awake state, makes the awareness of activity significantly reduced. One of the important discoveries of physiology in the last twenty years as A. Luria argues is the significant role in this process play the formation of the upper parts of the brain stem, in particular, the formation of the hypothalamus, optic tubercle, and the system of retinal fibres, which combines these two formations with the cerebral cortex. These formations are included as the main part of the «first block» of the human brain, which provides a general tone, or capable state of the cortex, a normal emotional state and creates the conditions for the strong retention of the once-emergent traces. There are three main sources of supporting the brain cortex tone. The first source is the constant flow of information from the outside world, an important role played by the formation of the upper parts of the brain stem, united by a system of retinal fibres. The second source is the impulses that reach it from the body's internal, metabolic processes, which form the basis of biological desires. The third source is provided by close connections with the cortex of the filamentous fibres, which have both ascending and descending fibres. The ascending (upper) mesh fibres excite the cortex with impulses that come from the upper brain stem, and with the descending (lower) mesh fibres influence those that play a significant role in providing the tone of affective colour and tone behaviour and realization of needs and desires that are formulated by a person through speech. If the first block of the brain provides the tone of the cortex, but is not yet involved in the reception and processing of information or in the creation of a program of behaviour, then the second block is directly related to the work of analysis and synthesis of signals provided by the senses from the outside world, ie provides reception, processing and storage of information 
received by a person. This unit includes devices that are located in the posterior brain (parietal, temporal, and occipital), and are a system of central organs that perceive visual, auditory, and tactile information, process, or «encode» it and store it in memory as experience. Information coming from the visual, auditory and tactile receptors is divided into a huge number of features, for which certain highly specialized neurons are responsible, whereby a person responds only to individual, partial signs of stimuli. The third block of the human brain carries out the programming, regulation and control of active human activity. It includes devices located in the anterior compartments of the large hemisphere, the leading place in it is occupied by the departments of the brain. Conscious human activity only begins with the receipt and processing of information, and ends with the formation of intentions, the development of an appropriate program of action and the implementation of these programs in external (motor) or internal (mental) acts. This requires a special apparatus that can create and retain the right intentions, produce appropriate action programs, implement them in the necessary acts and, very significantly, constantly monitor the flowing actions, comparing the effect of the action with the original intentions. All these functions are performed by the anterior brain and their frontal lobes. Especially important is the fact that the frontal lobes of the brain play a significant role in the ongoing monitoring of the flow of activity, in ensuring self-regulatory human activity. The aforementioned hereditary motives of functioning of the cerebral hemispheres, principles of development of the nervous system, blocks of functions of the brain, sources of support for the capacity (tone) of the cerebral cortex determine the biological preconditions for human intellectual development. On this basis, E. Kaindell ${ }^{5}$ identifies the basic biological principles of human learning as a completed and of learning aimed at developing emotional intelligence, in particular at the cellular level. Firstly, the elementary aspects of learning are not diffusely distributed throughout the brain, but localized in the activity of certain nerve cells. Secondly, learning occurs as a result of changes characterized by

5 Реан А.А. Агрессия и агрессивность личности// Психологический журнал. 1996. № 5. C. 3-18. 
combinations between cells in such a way that not new combinations arise, but existing ones are fixed. Thirdly, long-lasting and persistent changes in the sensory connections occur as a result of changes in the amount of the transmitter (a biologically active substance involved in the transmission of excitement from the nerve end to the working organs (muscles, glands, etc.) and from one nerve cell to another (at the synapses), which is excreted at the endings of the neurons in those areas through which one cell communicates with others. Fourthly, the simple processes of fixing synaptic connections can be combined to explain how complicated underlying mental processes occur. This allows us to conclude that the potential of many behaviours that the body is capable of is laid down in the formation of the brain and controlled by genes and the process of development. Organisms themselves are capable of certain behaviours, but not all of them. We should consider if one adheres to the biological approach to the phenomenon of cognition. The above principles, with some modification, can be applied to explain how a person's cognitive systems develop, how he or she masks certain intellectual skills, going in a particular direction. The influence of the enriched (or impoverished) early experience, maximally influences on the further development of the general functions of the body. For example, malnutrition in childhood unambiguously affects the body, leads to devastating consequences of both cognitive and emotional functioning. In the context of our study, the organizational structure of the nervous system as a basis for the development of emotional intelligence will be considered at two separate levels: the level of molecular structure and the level of molar structure. At the level of molecular structure, the cerebral cortex consists of miniature columns of about $3 \mathrm{~mm}$ in length and $0.5-1 \mathrm{~mm}$ in height, which are located near the surface of the cortex; they are combined into macro columns that unite hundreds of miniature columns each. Each group of macro columns is responsible for specific areas and has clearly defined boundaries (visual, auditory, etc.). The enlarged areas of the cerebral cortex are called molarlevel zones which can be seen with the naked eye (without magnifying devices). One of the hemispheres performs non-identical functions, and under certain conditions the functions of one of the hemispheres dominate. For example, it is known that if the function of the left 
hemisphere is dominant, then the person is right-handed, and if the right one is left-handed. The left hemisphere is responsible for speech in the majority of the right-handed, and the right hemisphere dominates, as a rule, when performing visuospatial functions. Thus, it can be argued that in a normal adult, emotional and intellectual function can be correlated with certain areas of the brain that retain relatively clear boundaries. All this is a prerequisite for the existence of the biological basis of different types of intelligence, says G. Gardner, because the discoveries of neuroscience at the molecular and molar levels give a more or less complete idea of what «natural types» of human intelligence exist. Of course, we cannot exclude the cultural environment, whether we want it or not, the culture of the society in which a person lives are necessarily imprinting on everyone's intellectual potential. The legitimacy of the assumption that emotional intelligence is related to functional asymmetry of the brain, in particular, the dominance of the right hemisphere I. Andreeva explains that the right hemisphere type of thinking is associated with non-verbal intelligence, it contributes to accurate recognition of emotional recognition. People with advanced non-verbal intelligence are emotionally-mobile, more focused on others than themselves, are better able to recognize emotions ${ }^{6}$. For example, «right hemisphere» musicians better identify the emotional states of the interlocutor than «left hemisphere» maths ${ }^{7}$. Musicians and vocalists have a more developed ability to adequately perceive the emotional state of a person by her voice, according to A. Pashin ${ }^{8}$, and individuals of «artistic» type have more expressed ability to correctly determine the type of emotional context of speech, they are more empathetic and anxious 9 . Thus, the right-hemisphered type of thinking promotes more accurate recognition of other people's emotions. This type of thinking is

\footnotetext{
${ }^{6}$ Лабунская В.А. Психология затрудненного общения: Теория. Методы. Диагностика. Коррекция / В.А. Лабунская. - М. : Академия, 2001. - 356 с.

7 Ермолаева М.В. Психология развития. - М. : Изд-во Московского психологосоциального ин-та ; Воронеж : МОДЭК, 2006. - 376 с.

${ }^{8}$ Пашина А.Х. О структуре эмоционального слуха / А.Х. Пашина // Психологический журнал. - 1992. - Т. 13. - № 3. - С. 76-83.

9 Пашина А.Х. Художественный и мыслительный типы личности: особенности эмоциональной сферы / А.Х. Пашина // Психологический журнал. - 1994. - Т. 15. - № 3. - C. 89-98.
} 
a hereditary deposit of emotional receptivity, which characterizes the successful adaptation of an emotional response to a stimulus in certain circumstances and is associated with the effective processing of emotionrelated information.

The biological prerequisite for the development of emotional intelligence is personality temperament, because along with activity, the basic parameter of temperament is emotionality, which is regarded as a stable tendency to experience emotions of a certain modality and sign ${ }^{10}$, as a certain set of personality traits that determine the adequacy or inadequacy of emotional reactions of a person in different usual situations $^{11}$. According to O. Sannikova, emotionality performs a systemforming function both in the structure of the individual as a whole and in some of its peculiarities, which include intelligence, in particular ${ }^{12}$. In this case, people of different types of emotionality are distinguished by the specificity of the component composition of intelligence, which indicates that this trait of temperament is one of its individually typological determinants ${ }^{13}$. The properties of temperament are related to the innate motives of emotional receptivity. Temperament and intelligence are characteristics of the instrumental sphere of individuality, only temperament characterizes it in terms of activity, energy, and intelligence from terms of the subject's ability, ability to dispose of that energy ${ }^{14}$. In the structure of each of these mental phenomena there are common fundamental energy-informative processes

\footnotetext{
${ }^{10}$ Небылицин В.Д. Психофизиологические исследования индивидуальных различий / В.Д. Небылицин. - М. : Наука, 1976.

${ }^{11}$ Пашко Т.А. Психологічні засади формування емоційної культури сучасної молоді / Т.А. Пашко // Проблеми загальної та педагогічної психології : зб. наук. пр. Ін-ту психології ім. Г.С. Костюка АПН України / [за ред. С.Д. Максименка]. - К., 2007. T. IX. - Ч. 1. - C. 322-327.

12 Санникова О.П. Эмоциональность в структуре личности / О.П. Санникова. Одесса : Хорс, 1995. - 334 с.

13 Черножук Ю.Г. Індивідуальні відмінності емоційності у співвідношенні 3 особливостями інтелекту : автореф. дис. ... канд. психол. наук : 19.00.01 «Загальна психологія, історія психології»/ Ю.Г. Черножук. - Одеса : Південноукраїнський державний пед. університет ім. К.Д. Ушинського, 2006. - 22 с.

14 Либин А.В. Дифференциальная психология: На пересечении европейских, российских и американских традиций / А.В. Либин. - М. : Смысл : Pez Se, 2000. - 344 с.
} 
that depend on the same biological properties of a person (or makings) ${ }^{15}$. Due to this, I. Andyreyeva concludes that, apparently, intellect, along with the properties of temperament, is included in a single system of psychological properties. Features of human temperament include mainly such personal characteristics as neuroticism, extraversion, mindfulness, which correlate with the questionnaires of the study of emotional intelligence ${ }^{16}$. This means that the properties of temperament in conjunction with emotional intelligence form a certain personality trait of the person. S. Dudin and V. Rusalov found out that temperament and intellectual abilities interact first of all, depending on the level of development of such characteristics of activity as: vigour, plasticity and tempo. For example, the plasticity of the connections between the mentioned substructures depends on two parameters: age (in adolescents this connection is much stronger than in people of other age) and the level of mental development (the higher the intellect, the weaker the connections between the named signs of personality) ${ }^{17}$. Along with activity, the basic parameter of temperament is emotionality. A high level of emotionality is seen as an indicator of emotional intelligence and is better manifested in extroverts ${ }^{18}$. In most cases, emotions of a certain nature depend on the peculiarities of temperament. V. Druzhinin submits that extrovert orchestrators try to perform works that evoke feelings of joy, activity, spiritual upliftment, and avoid works that cause feelings of sadness, and introverts avoid performing works that evoke feelings of anger, joy, and activity.

Different opinions exist as if neuroticism is a biological precondition for emotional intelligence. K. Brandt and V. Egan claim that the level of general intelligence increases with increasing levels of neuroticism ${ }^{19}$.

15 Русалов В.М. О связи общих способностей с «интеллектуальными» шкалами темперамента / В.М. Русалов, Е.Р. Наумова // Психологический журнал. - 1999. - Т. 20. № $1 .-$ C. $70-77$.

${ }^{16}$ Робертс Р. Эмоциональный интеллект: проблемы, теории, измерения и применения на практике / Р. Робертс // Психология. Журнал Высшей школы экономики. - 2004. T. 1. - № 4. - C. 13-26.

${ }^{17}$ Русалов В.М. Темперамент и интеллект: общие и специальные факторы развития / В.М. Русалов, С.И. Дудин // Психологический журнал. - 1995. - № 5. - С. 12-23.

${ }_{18}$ Русалов В.М. Опросник структуры темперамента : метод. пособ. / В.М. Русалов. М. : ИПАН, 1990. - С. 4-27.

${ }^{19}$ Додонов Б.И. В мире эмоций / Б.И. Додонов. - Киев, 1987. - 288 с. 
P. Lopez, P. Salovey, and R. Strauss prove that emotional intelligence is negatively associated with neuroticism ${ }^{20}$. Features of temperament such as extraversion and neuroticism are related to information processing. $\mathrm{R}$. Robert argues for the existence of individual differences in the processing of positive and negative incentives. Eextraversion promotes the processing of positive, and neuroticism of negative stimuli as a rule. There are assumptions about the presence of cognitive factors that contribute to the processing of cognitively stimulated stimuli, and therefore affect the level of emotional intelligence. However, it is not proven how useful for the body is the rapid processing of positive stimuli and the slow processing of negative stimuli (or vice versa). In general, each person is born with the compulsory certain potential of emotional memory, emotional processing, emotional learning, emotional sensitivity. These four innate components, as noted by G. Berezyuk, form the core of emotional intelligence, though each person has a different process: a person can start life with a high level of emotional intelligence, but over time it can be reduced if the person acquires harmful emotional habits as a child in a family where he or she was abused or disrespected ${ }^{21}$. It would be a profound mistake to believe that emotions simply cause a general arousal or a feeling of a surge of energy, says K. Izard ${ }^{22}$. He and a group of scientists (K. Nagler, S. Randall, D. Fox) experimentally found that the most common and fundamental principle of human behaviour is that emotions charge energy and organize thought and activity. Specific emotion excites a person to a particular activity and this is the first sign that emotion organizes thinking and activity. Thus, emotional and cognitive processes are closely intertwined and confirm that emotions are the result of biological processes, and cognitive processes contribute to the use of emotions in the adaptation of man to a constantly changing environment. I. Singer, K. Izard, and S. Tomkins believe that environmental novelty activates the emotion of interest, which in turn enhances human

\footnotetext{
${ }^{20}$ Lopes P.N. Emotional intelligence, personality, and perceived quality social relationships /

P.N. Lopes, P. Salovey, R. Straus // Pers. Individ. Diff. - 2003. - № 35. - P. 641-658.

${ }^{21}$ Березюк Г. Емоційний інтелект як детермінанта внутрішньої свободи особистості /

Г. Березюк // Психологічні студії Львівського ун-ту. - 2007. - С. 20-23.

${ }^{22}$ Изард К.Э. Психология эмоций / К.Э. Изард. - СПб. : Питер, 2007. - 464 с.
} 
exploratory activity, whereby environmental cognition and successful adaptation reduce excitement and activate emotion as joy a large number of complications can cause fear, sadness, or fright. Emotions combined with actions contribute to the fact that a person learns to understand the various affective manifestations, learns to control their emotions, thoughts and behaviour, it forms a sense of competence, develops selfcontrol and other positively directed processes.

Thus, the most essential biological prerequisites for the development of emotional intelligence are hereditary inclinations of emotional abilities and emotional perception, the right-hemisphered type of thinking, the properties of temperament; features of information processing.

\section{Social Prerequisites for the Development of Emotional Intelligence}

Emotional intelligence can be developed and there are objective social prerequisites $^{23}$. Social life transforms intelligence through the influence of certain mediators. According to J. Piaget ${ }^{24}$, these mediators are: speech (signs), the content of the interaction of the subject with the objects (intellectual values) and rules defined for thinking (group, logical and methodological rules). In sociology, society is defined as the totality of interaction between individuals, in psychology, the main unit of analysis is no longer the totality of relationships as such, but the individual, which changes as a result of changes in social relations. Depending on the level of development of the individual, the nature of his interaction with the social environment may be quite different and, in turn, may, accordingly, differently change his individual mental and intellectual structure. As the individual becomes master of speech, he or she changes social relations with others, which enrich and transform his or her thinking. In this process, there are three sides. Firstly, the knowledge system as such is not a sufficient means of expression, the individual wants to do what he sees fit, express his thoughts through

23 Зарицька В.В. Соціальні передумови розвитку емоційного інтелекту / В.В. Зарицька // Проблеми загальної та педагогічної психології : зб. наук. пр. Інституту психології ім. Г.С. Костюка АПН України / [за ред. С.Д. Максименка]. - К., 2007. T. IX. - Ч. 6. - С. 154-160.

${ }^{24}$ Пиаже Ж. Психология интеллекта / Ж. Пиаже. - СПб. : Питер, 2003. - 192 с. 
speech, gestures or objects, to imagine things through imitation, drawing or individual symbolism. Secondly, broadcasting conveys to the individual a ready, formed system of concepts, classifications, relationships, that is, the inexhaustible potential of ideas that are built by each individual according to a model that has been worked out by previous generations. Thirdly, the relationships in which the individual interacts with his or her environment and from whom he or she is influenced, remain the mastery of speech and related ways of thinking: by talking with others, the individual observes how much their thoughts confirm or contradict their thoughts, and he or she is gradually discovering a vast world of outside thoughts that give him or her new insights or differently influence his or her impressions. Thus, the development of the subject's intelligence goes through a more intensive exchange of intellectual values and is subject to a greater number of compulsory truths, which are understood as well-formed thoughts or norms of reasoning. No matter how dependent the individual is on the surrounding intellectual influences, he or she assimilates them in own way: he or she reduces all these influences to own point of view, thus, without noticing, deforms them. As social experience is gained, the individual becomes not only an object of intellectual compulsion, but also acts as a subject of socialization, capable of profoundly altering the mechanism of development of the intelligence. According to a similar scheme, in our opinion, any kind of intelligence, including emotional intelligence, develops. Based on numerous studies related to the understanding of intelligence as a set of interconnected mental abilities and in accordance with the approach to understanding emotions as a specific type of knowledge, I. Andreeva ${ }^{25}$ defines the concept of «emotional intelligence» as a set of mental abilities to understand their own emotions, emotions of other people, and control the emotional sphere and highlights the following social prerequisites for the development of emotional intelligence: syntonicity in childhood, the development of rationality as they grow older, the level of development

25 Андреева И.Н. Биологические и социальные предпосылки развития эмоционального интеллекта / И.Н. Андреева // Когнитивная психология: сб. ст. / [под ред. А.П. Лобанова, Н.П. Радчиковой]. - Минск: БГПУ, 2006. - С. 7-11. 
consciously those favourable emotional relationships between parents, parents' education and family welfare, gender peculiarities education, androgyny, locus of control, religion. The term «syntony» is understood as an instinctive harmony with others, that is, a natural instinct, a reaction of the type of unconditional emotional reflex of the innate mechanism of release, or as an acquired reaction ${ }^{26}$. The development of syntony is related to the emotional reactions of the environment to the actions of the child, which are guidelines for her self-esteem and selfesteem. The foundations of realistic self-perception and self-perception are laid in the early stages of ontogeny, determined by the parent's initial acceptance of the child (A. Kravchenko) ${ }^{27}$. The following factors hinder the development of a child's syntonicity: firstly the parent's overprotection and reassessment, because in the conditions of constant care of the parents, their excessive love in the child, there is no need to strive for emotional contact with adults, whereby mechanisms that allow it to do so are formed; secondly the development of syntony is blocked if the child, potentially incapable of making emotional contact, is unable to do so because of the indifference or hostility of the environment. Asynthony, which results from the deprivation of the need for emotional contact, impedes the process of expressing emotions by the subject and understanding by his or her communication partners. Syntonicity in childhood is a necessary stage of mental development. At the same time, syntonicity, which persists until adulthood, indicates a developmental disturbance, because as logical and causal thinking develops, syntony develops into empathy, which is not so much emotional consonance with the condition of another person, but the recognition of a given emotional state (M Goffman) ${ }^{28}$. Due to the fact that in the course of normal development in the person develops a tendency to reflection, there is a natural weakening of syntonicity in favour of independence from the outside world and the attempt to counter the affective influences of others. Thus, the mechanisms of rational thinking press on the

\footnotetext{
${ }^{26}$ Mazurkiewicz. Wstep do psychofiziologii normainey. - Warszawa: PZWL, 1950. - T. 1.

27. Кравченко А. Нарцисс и его отражение / А. Кравченко // Моск. психотерапевт. 2001. - № 2 .

${ }^{28}$ Hoffman M. Empathy, role taking and development of altruistic motives. (In:) M. Takela (ed.). Moral development and behavior. - N.Y., Holl. - 1976
} 
immediacy of the lower feelings. Negative affective influence is counteracted by the rational attitude towards others and events. The rationality of actions, that is, the choice of a particular pattern of behaviour depends on the person's understanding of what he or she will feel, and how he will act depending on what emotions he or she would like to feel and which ones to avoid. The use of rational statements reduces emotional distress and reduce the intensity of both «inappropriate» emotions (anger, depression, etc.) and «appropriate» (irritation, sadness, agitation, and more).

An important social prerequisite for the development of emotional intelligence is the level of development of self-consciousness, which means a person's firm belief that he or she as a person deserves high praise and value for society. The level of development of selfconsciousness, self-esteem determines the level of self-regulation of human activity, which is expressed in the specificity of mental means of reflection and modelling of reality, including reflection of the subject. Self-regulation can be manifested in different ways, but it always has a certain structure: a person determines the purpose of his or her arbitrary activity, has a program of executive actions, by certain criteria evaluates the success of the activity, makes decisions about the necessity and nature of corrective activity. The holders of self-regulation are various psychic forms of reflection of reality, and methods are sensory concrete images, representations, concepts, etc., which depend on the type of activity, conditions of its presenting, individual personality characteristics of the nervous system, personal qualities, ability to organize their actions. Mechanisms of self-regulation, as well as syntonicity and rationality, are laid at the earliest stages of personality development. The whole system of personal self-regulation is based on self-awareness (Ye. Grebennikova) [90]. It turns out that the level of development of self-awareness acts as a prerequisite for managing one's emotions.

The social prerequisite for the development of emotional intelligence is the emotional and favourable relationship between parents. How people interact with each other in the family circle, notes G. Craig ${ }^{29}$,

\footnotetext{
${ }^{29}$ Крайг Г. Психология развития / Г. Крайг. - СПб. : Питер, 2002. - 992 с.
} 
directly affects the development of the child. Each family member plays a role in interacting with other family members ${ }^{30}$. If parents have warm emotional relationship, they over the years are transferred to close emotional relationships between parents and children and children between each other. However, in addition to the overall experience of family relationships, each family member has personal experience. The key points of emotionally-positive relationships in the family are the emotional background in the family, the parent's responsiveness to the child, and the parents' chosen methods of controlling the child's life. Parents with emotionally warm relationships worry about the baby, express their love, often or regularly put the baby's needs first. In a warm loving family, children are more likely to have a secure attachment in the first two years of life; have a higher self-esteem, are more empathetic and altruistic, and are more responsive to other people's pain or fear; have higher intelligence ratios in pre-school and primary school, better at school. Children who grow up in a warm emotional atmosphere are less aggressive and less likely to exhibit delinquent behaviour, confident, active and calm. Children who do not have such emotional support are vulnerable, aggressive, display uncertainty, have inadequate self-esteem and other negative manifestations. G. Orme's research shows that people who are satisfied with their family life have a much higher EQ than those who are not satisfied ${ }^{31}$. According to N. Newcomb ${ }^{32}$, parental qualities that provide children with satisfaction in their family life include social maturity, emotional adaptation, ideas about the child's motivation and ability.

An important social prerequisite for the development of emotional intelligence is the level of education of parents and their family wellbeing. The higher these indicators is the higher the level of emotional intelligence, in particular, in adolescents (N. Harrod, S. Scheer) ${ }^{33}$. Maoki-Taylor identified two major factors that are social preconditions

\footnotetext{
${ }^{30}$ Би Х. Развитие ребенка / Х. Би. - 9-е изд. - СПб. : Питер, 2004. - 768 с.

${ }^{31}$ Орме Г. Эмоциональное мышление как инструмент достижения успеха / Г. Орме. М. : КСП+, 2003. -272 c.

${ }^{32}$ Ньюкомб Н. Развитие личности ребенка / Н. Ньюкомб. - СПб. : Питер, 2003. - 640 с.

33 Гребенщикова Э.А. Саморегуляция личности в индивидуальном стиле жизнедеятельности : автореф. дис. ... канд. психол. наук : 19.00.05 / Э.А. Гребенщикова / Рос. акад. гос. службы при президенте Рос. Фед., каф. соц. психологии. - М., 1995. - 20 с.
} 
for the development of emotional intelligence. The first factor is the home environment, which is heterogeneous, which gives rise to two assumptions that describe the mechanisms of formation of differences in the cognitive sphere. According to the first assumption, different aspects of family living conditions affect different characteristics of development; the second assumes the possibility of indirect influence of living conditions on the level of cognitive development due to intensive development of other spheres (eg, physical development). It is a wellknown hypothesis that the intellectual development of a child is related to the intellectual level of the home environment. The second factor is the level of parental skills. The impact of skill level on children's intellectual development can be mediated by factors such as: the style of education, the quality of education received by the child. The child's intelligence can be influenced by the emotional and psychological atmosphere in the family, the financial security, the features of pregnancy, complications during childbirth, blood type, etc. These two factors are inseparably complementary and stimulate or inhibit the development of emotional intelligence. No less important social precondition for the development of emotional intelligence is the gender peculiarities of education, which are manifested primarily in the predominance of women in interpersonal, and in men, intrinsic personal indicators. Emotional differences between adult men and women are known to be deterministic approaches to parenting from the outset. In general, boys tend to have more stable and more traditional gender-role stereotypes. But if children grow up without a father and the mother works, then both girls and boys have less rigid stereotypes. In addition, some girls try to look like boys in clothing, behaviour, and play. Sometimes, these girls are specially educated so that they are able to protect themselves. In this regard, androgyny as a gender-role identity that combines a number of positive aspects of both traditionally male and traditionally female behaviour can be seen as a consequence of a particular parenting strategy. Due to the special position of parents, who encourage the child to adopt patterns of behaviour, characteristic of female and male sex, contribute to the formation of androgynous personality. Such especially active formation occurs when such behaviour is modelled by the eyes of the child and accepted by others, 
which is achieved if one parent of the same sex with the child shows a pattern of androgynous behaviour, and the other parent of the opposite sex approves of such actions. A person has the opportunity to feel and behave in both male and female. Such a mixture of human qualities, which do not limit the person in his or her actions, forms what is called androgynous personality. Depending on the circumstances, a person exhibits features of a particular gender. For example, men with androgynous traits can be independent, strong, courageous, determined and yet gentle, caring, attentive to others, and women, on the contrary, along with manifestations of feelings, emotions, can be resolute, courageous and more. Androgyny acts as an all-encompassing characteristic of a person, relating to all spheres of identity, lifestyle, physicality of emotion, sphere of profession, work, choice of partner and more. Absolutely sexually role-fixing is a pathology because a person can manifest male and female sides in the profession, interests and feelings ${ }^{34}$.

Another social prerequisite for the development of emotional intelligence is the external locus of control. The locus of control, according to D. Rotter's theory, is a generalized expectation of the extent to which people control reinforcement in their lives. The locus of control is called external if people are convinced that their successes and failures are governed by external factors, and internal when people believe that their successes and failures are determined by their own actions and abilities. L. Wang, N. Anderson argue that subjects with external locus control tend to forgive both others and themselves, and with internal locus control more often condemn themselves and more meticulous when condemning others ${ }^{35}$. The ability to forgive is related to the awareness and control of one's emotions, the empathy towards the offender. Each person needs experience in two quite different areas of interrelationships: vertical and horizontal communication. Vertical relationships include a relatively long emotional bond at the heart of which a person's sense of security is linked to a relationship with another

\footnotetext{
${ }^{34}$ Александров А.А. Психотерапия: учеб. пособ. / А.А. Александров. - СПб.: Питер, 2004. $-480 \mathrm{c}$.

${ }^{35}$ Wanq L. Excuse-making and blaming as a function of internal-external locus of control / L. Wanq, N.H. Anderson // Eur. Psychol. - 1994. - V 24. - № 2.
} 
person who has greater social power or knowledge. Horizontal relationships are reciprocal and equal, communication partners, such as peers, have equal social power. Both vertical and horizontal relationships contribute to the development of external locus of control, which is important for the development of emotional intelligence. First and foremost, it is the relationships between parents and children that are vital because they provide the child with everything they need. The key feelings in this relationship are emotional connection, affection and attachment behaviour. Emotional intelligence in this case develops according to the comfort level of the relationship. Uncomfortable relationships reduce the emotional development of the child or form distorted ideas and inappropriate behaviour.

The relationship between religiosity and emotional intelligence is traced. Religious individuals are dominated by an external locus of control. Religious education involves the cultivation of a sense of unconditional love. Preparation for the sacraments (confession, communion) is impossible without introspection of the activity and its accompanying emotions. Therefore, emotional intelligence is a phenomenon that is being researched by scientists from different countries, it can be developed and there are objective social prerequisites.

\section{CONCLUSIONS}

The most essential biological prerequisites for the development of emotional intelligence are hereditary inclinations of emotional abilities and emotional perception, the right-hemisphered type of thinking, the properties of temperament; features of information processing.

The most important social prerequisites are the following: childhood syntony; development of rationality as we grow older; the level of development of consciousness; emotionally-supportive relationships between parents; parental education level and family well-being; gender peculiarities of education; androgyny; external locus of control; religiosity.

\section{SUMMARY}

The section deals with brain functioning specificity, the principles of the nervous system development and learning principles that determine 
biological preconditions of emotional and intellectual development. The essence of dominating preconditions is revealed: inherited disposition of emotional abilities and perception, right-hemisphere type of thinking, temperamental characteristics, specificity of information processing.

The section reveals the influence of social factors on the development of the person's emotional intelligence, substantiates their essence, describes the views of domestic and foreign scientists on this problem. We focuses on social factors such as: synthonics in childhood; development of rationality as it grows; level of self-awareness; emotional and beneficial relationships between parents; level of education of parents and family welfare; gender peculiarities of upbringing in the family; androgyny; locus of control; religiosity. In particular, the accents are made on the characteristics of the positive influence of social factors on the development of emotional intelligence as a necessary ability of the individual for its successful communication and interaction with other people. Two main ways of preventing the negative influence of social factors on the development of the emotional intelligence of the person proposed by $\mathrm{H}$. Bee are proposed, with which we agree: 1) the sequence of the complication of the child's requirements with a clear regulation of their implementation; 2) the level of expectation from the child must be consistent with her age. We have supplemented these rules with the following: the child's work should be judged by the results rather than praise, because an inappropriate excessive self-esteem is formed in the adopted child and help where it is still difficult.

\section{REFERENCES}

1. Гарднер Г. Структура разума: теория множественного интеллекта / Г.Гарднер. - М. : Вильямс, 2007. - 512 с.

2. Андреева И.Н. Предпосылки развития эмоционального интеллекта / И.Н. Андреева // Вопросы психологии. - 2007. - № 5. C. $57-65$.

3. Андреева И.Н. Биологические и социальные предпосылки развития эмоционального интеллекта / И.Н. Андреева // Когнитивная психология: сб. ст. / [под ред. А.П. Лобанова, Н.П. Радчиковой]. - Минск: БГПУ, 2006. - С. 7-11. 
4. Реан А.А. Социализация агрессии / А.А. Реан, Я.Л. Коломинский // Социальная педагогическая психология. СПб., 1999. - 398 с.

5. Реан А.А. Агрессия и агрессивность личности// Психологический журнал. 1996. №5. С.3-18.

6. Лабунская В.А. Психология затрудненного общения: Теория. Методы. Диагностика. Коррекция / В.А. Лабунская. - М. : Академия, 2001. - 356 с.

7. Ермолаева М.В. Психология развития. - М. : Изд-во Московского психолого-социального ин-та ; Воронеж : МОДЭК, 2006. - $376 \mathrm{c}$.

8. Пашина А.Х. О структуре эмоционального слуха / А.Х. Пашина // Психологический журнал. - 1992. - Т. 13. - № 3. - С. 76-83.

9. Пашина А.Х. Художественный и мыслительный типы личности: особенности эмоциональной сферы / А.Х. Пашина // Психологический журнал. - 1994. - Т. 15. - № 3. - С. 89-98.

10. Небылицин В.Д. Психофизиологические исследования индивидуальных различий / В.Д. Небылицин. - М. : Наука, 1976.

11. Пашко Т.А. Психологічні засади формування емоційної культури сучасної молоді / Т.А. Пашко // Проблеми загальної та педагогічної психології : зб. наук. пр. Ін-ту психології ім. Г.С. Костюка АПН України / [за ред. С.Д. Максименка]. - К., 2007. - T. IX. - Ч. 1. - C. 322-327.

12. Санникова О.П. Эмоциональность в структуре личности / О.П. Санникова. - Одесса : Хорс, 1995. - 334 с.

13. Черножук Ю.Г. Індивідуальні відмінності емоційності у співвідношенні з особливостями інтелекту : автореф. дис. ... канд. психол. наук : 19.00.01 «Загальна психологія, історія психології» / Ю.Г. Черножук. - Одеса : Південноукраїнський державний пед. університет ім. К.Д. Ушинського, 2006. - 22 с.

14. Либин А.В. Дифференциальная психология: На пересечении европейских, российских и американских традиций / А.В. Либин. М. : Смысл : Pez Se, 2000. - 344 c.

15. Русалов В.М. О связи общих способностей с «интеллектуальными» шкалами темперамента / В.М. Русалов, 
Е.Р. Наумова // Психологический журнал. - 1999. - Т. 20. - № 1. C. 70-77.

16. Робертс Р. Эмоциональный интеллект: проблемы, теории, измерения и применения на практике / Р. Робертс // Психология. Журнал Высшей школы экономики. - 2004. - Т. 1. - № 4. C. 13-26.

17. Русалов В.М. Темперамент и интеллект: общие и специальные факторы развития / В.М. Русалов, С.И. Дудин // Психологический журнал. - 1995. - № 5. - С. 12-23.

18. Русалов В.М. Опросник структуры темперамента : метод. пособ. / В.М. Русалов. - М. : ИПАН, 1990. - С. 4-27.

19. Додонов Б.И. В мире эмоций / Б.И. Додонов. - Киев, 1987. $288 \mathrm{c}$.

20. Lopes P.N. Emotional intelligence, personality, and perceived quality social relationships / P.N. Lopes, P. Salovey, R. Straus // Pers. Individ. Diff. - 2003. - № 35. - P. 641-658.

21. Березюк Г. Емоційний інтелект як детермінанта внутрішньої свободи особистості / Г. Березюк // Психологічні студії Львівського ун-ту. - 2007. - С. 20-23.

22. Изард К.Э. Психология эмоций / К.Э. Изард. - СПб. : Питер, 2007. - $464 \mathrm{c}$.

23. Зарицька В.В. Соціальні передумови розвитку емоційного інтелекту / В.В. Зарицька // Проблеми загальної та педагогічної психології: зб. наук. пр. Інституту психології ім. Г.С. Костюка АПН України / [за ред. С.Д. Максименка]. - К., 2007. - Т. ІХ. - Ч. 6. C. $154-160$.

24. Пиаже Ж. Психология интеллекта / Ж. Пиаже. - СПб. : Питер, 2003. - 192 с.

25. Андреева И.Н. Биологические и социальные предпосылки развития эмоционального интеллекта / И.Н. Андреева // Когнитивная психология: сб. ст. / [под ред. А.П. Лобанова, Н.П. Радчиковой]. - Минск: БГПУ, 2006. - С. 7-11.

26. Mazurkiewicz. Wstep do psychofiziologii normainey. Warszawa: PZWL, 1950. - T. 1.

27. Кравченко А. Нарцисс и его отражение / А. Кравченко // Моск. психотерапевт. - 2001. - № 2. 
28. Hoffman M. Empathy, role taking and development of altruistic motives. (In:) M. Takela (ed.). Moral development and behavior. - N.Y., Holl. - 1976.

29. Крайг Г. Психология развития / Г. Крайг. - СПб. : Питер, 2002. $-992 \mathrm{c}$.

30. Би Х. Развитие ребенка / Х. Би. - 9-е изд. - СПб. : Питер, 2004. $-768 \mathrm{c}$.

31. Орме Г. Эмоциональное мышление как инструмент достижения успеха / Г. Орме. - М. : КСП+, 2003. - 272 с.

32. Ньюкомб Н. Развитие личности ребенка / Н. Ньюкомб. СПб. : Питер, 2003. - 640 с.

33. Гребенщикова Э.А. Саморегуляция личности в индивидуальном стиле жизнедеятельности : автореф. дис. ... канд. психол. наук : 19.00.05 / Э.А. Гребенщикова / Рос. акад. гос. службы при президенте Рос. Фед., каф. соц. психологии. - М., 1995. - 20 с.

34. Александров А.А. Психотерапия: учеб. пособ. / А.А. Александров. - СПб.: Питер, 2004. - 480 с.

35. Wanq L. Excuse-making and blaming as a function of internalexternal locus of control / L. Wanq, N.H. Anderson // Eur. Psychol. 1994. - V 24. - № 2.

\section{Information about the author: Zarytska V. V.,}

Doctor of Psychological Sciences, Professor, Head of the Department of Practical Psychology, Classic Private University 70b, Zhukovsky str., Zaporizhzhya, 69002, Ukraine

Falko N. M., $\mathrm{PhD}$ in Psychology, Associate Professor, Head of the Department of Psychology, Bogdan Khmelnitsky Melitopol State Pedagogical University 